\title{
Recent advancements in the management of retinoblastoma
}

\section{and uveal melanoma [version 1; peer review: 2 approved]}

\author{
Amy C Schefler ${ }^{1,2}$, Ryan S Kim ${ }^{1,3}$ \\ ${ }^{1}$ Retina Consultants of Houston, Houston, TX, 77030, USA \\ ${ }^{2}$ Blanton Eye Institute, Houston Methodist Hospital, Houston, TX, 77030, USA \\ ${ }^{3}$ McGovern Medical School, University of Texas Health Science Center at Houston, Houston, TX, 77030, USA
}

V1 First published: 18 Apr 2018, 7(F1000 Faculty Rev):476

https://doi.org/10.12688/f1000research.11941.1

Latest published: 18 Apr 2018, 7(F1000 Faculty Rev):476

https://doi.org/10.12688/f1000research.11941.1

\section{Abstract}

Retinoblastoma and uveal melanoma are the most common intraocular malignancies observed in pediatric and adult populations, respectively. For retinoblastoma, intra-arterial chemotherapy has dramatically improved treatment outcomes and eye salvage rates compared with traditional salvage rates of systemic chemotherapy and external beam radiation therapy. Intravitreal injections of chemotherapy have also demonstrated excellent efficacy for vitreous seeds. Uveal melanoma, on the other hand, is treated predominantly with iodine-125 plaque brachytherapy or with proton beam therapy. Major strides in uveal melanoma genomics have been made since the early 2000s, allowing ocular oncologists to better understand the metastatic risks of the tumor on the basis of specific genetic signatures. Loss-of-function mutations of the BAP1 gene are associated with the highest metastatic risk, whereas gain-of-function mutations of SF3B1 and EIF1AX often confer a better prognosis. Expression of a cancer-testis antigen called PRAME (preferentially expressed antigen in melanoma) has been shown to increase metastatic risks in both low-risk and high-risk melanomas. New therapeutic approaches, including molecular therapies and nanoparticle phototherapy, are currently being investigated as alternative treatment modalities for uveal melanoma.

\section{Keywords}

retinoblastoma, uveal melanoma, ocular tumors

\author{
Open Peer Review
}

Approval Status

1

2

version 1

18 Apr 2018

Faculty Reviews are review articles written by the prestigious Members of Faculty Opinions. The articles are commissioned and peer reviewed before publication to ensure that the final, published version is comprehensive and accessible. The reviewers who approved the final version are listed with their names and affiliations.

1. Zelia Correa ID, University of Cincinnati, Cincinnati, USA

2. Richard Carvajal, Columbia University Medical Center, New York, USA Any comments on the article can be found at the end of the article. 
Corresponding author: Amy C Schefler (acsmd@houstonretina.com)

Competing interests: No competing interests were disclosed.

Grant information: The author(s) declared that no grants were involved in supporting this work.

Copyright: @ 2018 Schefler AC and Kim RS. This is an open access article distributed under the terms of the Creative Commons Attribution License, which permits unrestricted use, distribution, and reproduction in any medium, provided the original work is properly cited.

How to cite this article: Schefler AC and Kim RS. Recent advancements in the management of retinoblastoma and uveal melanoma [version 1; peer review: 2 approved] F1000Research 2018, 7(F1000 Faculty Rev):476

https://doi.org/10.12688/f1000research.11941.1

First published: 18 Apr 2018, 7(F1000 Faculty Rev):476 https://doi.org/10.12688/f1000research.11941.1 


\section{Introduction}

Retinoblastoma and uveal melanoma, albeit rare, are the most commonly observed intraocular malignancies in pediatric and adult populations, respectively. Retinoblastoma occurs during early childhood in 1 per 16,000 people worldwide ${ }^{1}$, whereas uveal melanoma occurs on average in Caucasians in their fifties and sixties ${ }^{2}$. Recent advancements in the techniques used to treat these two types of cancer have drastically enhanced patient outcomes and eye salvage rates. In this review, we briefly discuss current treatment guidelines and some emerging topics in the management of primary retinoblastoma and primary uveal melanoma.

\section{Retinoblastoma}

Retinoblastoma presents unilaterally in approximately 60-70\% of cases and bilaterally in the remaining 30-40\%. In unilateral retinoblastoma, close to $90 \%$ of patients present with a sporadic mutation, whereas heritable mutations of the RBI gene (located at chromosome 13q14) with a known affected family member occur in approximately $10 \%$ (Table 1$)^{3,4}$. A small fraction of non-heritable retinoblastoma presents with a $M Y C N$ oncogene mutation that results in a unilateral, sporadic tumor ${ }^{5}$. Unlike unilateral disease, bilateral retinoblastoma is always due to a germline mutation and commonly presents earlier in life than unilateral cases. With the advent of improved sequencing techniques, mosaicism is increasingly being recognized in both unilateral and bilateral patients. The presence of a germline RB1 mutation increases the risk for secondary cancers, especially when retinoblastoma is treated with external beam radiation $(\mathrm{EBR})^{6}$.

Both the Reese-Ellsworth and the International Classification of Retinoblastoma (ICRB) systems can be used to classify retinoblastoma, although the latter, newer system has been widely adopted in the last decade (Table 2). ICRB divides retinoblastoma into five categories; class $\mathrm{A}$ is the least advanced and $\mathrm{E}$ is

Table 1. Comparison of characteristics between sporadic and hereditary retinoblastoma.

\begin{tabular}{|l|l|l|l|}
\hline & Sporadic & Germline & $\begin{array}{l}\text { Germline- } \\
\text { mosaic }\end{array}$ \\
\hline Number of mutated cells & One & All & Variable \\
\hline Laterality & $\begin{array}{l}\text { Always } \\
\text { unilateral }\end{array}$ & $\begin{array}{l}85 \% \text { bilateral, } \\
15 \% \text { unilateral }\end{array}$ & $\begin{array}{l}\text { Either unilateral } \\
\text { or bilateral }\end{array}$ \\
\hline Age of onset & $18-24$ months & $12-18$ months & Variable \\
\hline $\begin{array}{l}\text { Chance of inheritance to } \\
\text { offspring }\end{array}$ & $0 \%$ & $45 \%$ & Variable \\
\hline
\end{tabular}

Table 2. Summary of Reese-Ellsworth and International Classification of Retinoblastoma (ICRB) classification systems.

\begin{tabular}{|c|c|}
\hline Reese-Ellsworth classification & International Classification of Retinoblastoma \\
\hline $\begin{array}{l}\text { Group } 1 \\
\text { - 1a: solitary tumor less than } 4 \text { disc } \\
\text { diameter (DD) at or behind equator } \\
\text { - } 1 \text { b: multiple tumors all under } \\
\text { 4 DD at or behind equator }\end{array}$ & Group A: tumors $<3 \mathrm{~mm}$ and away from fovea and optic disc \\
\hline 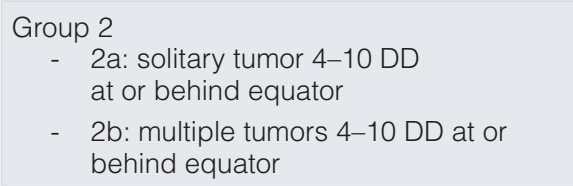 & $\begin{array}{l}\text { Group B: tumors }>3 \mathrm{~mm} \text {, located at macula/peripapillary region, or with } \\
\text { subretinal fluid }\end{array}$ \\
\hline $\begin{array}{l}\text { Group } 3 \\
-\quad \text { 3a: tumors anterior to equator } \\
\text { - } \quad \text { 3b: solitary tumor }>10 \text { DD behind the } \\
\text { equator }\end{array}$ & $\begin{array}{l}\text { Group C: tumors with focal vitreous or subretinal seeds within } 3 \mathrm{~mm} \text { of } \\
\text { tumor }\end{array}$ \\
\hline $\begin{array}{l}\text { Group } 4 \\
-\quad 4 a \text { : multiple tumors with some }>10 \text { DD } \\
-\quad 4 b \text { : any tumor extending to ora serrata }\end{array}$ & $\begin{array}{l}\text { Group D: tumors with diffuse vitreous or subretinal seeds }>3 \mathrm{~mm} \text { away from } \\
\text { tumor }\end{array}$ \\
\hline $\begin{array}{l}\text { Group } 5 \\
\quad-5 a \text { : tumors involving }>50 \% \text { of retina } \\
-\quad 5 b \text { : tumors with vitreous seeding }\end{array}$ & $\begin{array}{l}\text { Group E: tumors covering }>50 \% \text { of globe with or without neovascular } \\
\text { glaucoma, hemorrhage, extension of tumor to optic nerve/anterior chamber }\end{array}$ \\
\hline
\end{tabular}


the most advanced type ${ }^{7}$. Focal therapies such as laser ablation and cryotherapy can be used for retinoblastoma with ICRB classes $\mathrm{A}$ and $\mathrm{B}$, whereas more advanced cases (ICRB class $\mathrm{C}$, $\mathrm{D}$, or E) are preferentially treated with systemic chemotherapy or intra-arterial chemotherapy (IAC) over EBR or plaque brachytherapy because of their adverse effects. Enucleation of the eye is performed when there is a potential risk of extraocular extension, especially in class $\mathrm{E}$ eyes, or when all prior treatments have failed.

\section{Intra-arterial chemotherapy as primary treatment}

EBR was used as primary therapy for retinoblastoma in most cases until the early 1990 s and then intravenous chemotherapy (IVC) until the early 2000s. In 2004, a group of Japanese investigators reported a new technique of balloon-occluding the internal carotid artery distal to the ostium of the ophthalmic artery and then locally injecting melphalan to treat retinoblastoma $^{8}$. In 2008, Abramson et al. reported a more sophisticated technique of directly infusing melphalan into the ophthalmic artery with a microcatheter that many centers have now adopted with variations ${ }^{9}$. In this report, seven out of 10 eyes classified as Reese-Ellsworth V and originally scheduled for enucleation were salvaged by IAC. Numerous studies have since reported on the efficacy of IAC compared with that of IVC. In one study by Shields et al. ${ }^{10}$, global salvage rates for IAC and IVC for class D tumors were $91 \%$ and $48 \%$, respectively, demonstrating that IAC can be particularly successful at treating more advanced tumors. Therefore, at many large centers of excellence, IAC is the preferred treatment modality for unilateral and non-hereditary retinoblastoma. Bilateral retinoblastoma with a germline $R B 1$ mutation can be treated with either systemic chemotherapy or tandem IAC, in which IAC is performed in both eyes in a single IAC session ${ }^{11}$. In case the ophthalmic artery anatomy is not amenable to IAC, the external carotid artery can be alternately used to gain access to the ocular vasculature ${ }^{12}$. Most large centers have reported superior ocular salvage rates with IAC compared with systemic chemotherapy (Figure 1). Systemic treatment-related immediate effects such as immunosuppression are also rarer with IAC $^{13,14}$. Clinicians at centers that continue to use systemic chemotherapy have reported concerns about increased risks of metastatic retinoblastoma and risks of secondary cancers ${ }^{15,16}$. However, these controversies are unresolved with both fierce advocates and staunch opponents of IAC in existence with no clear sign of a definitive multi-center collaborative trial in the works that might settle the debate. As such, there continues to be a heterogeneity of treatment approaches in the US and abroad.

In many centers, IAC has been widely adopted as the primary therapy for retinoblastoma, and numerous publications have reported successful treatment outcomes. One of the recent reports, by Abramson et al., demonstrated that over $90 \%$ of patients now undergo IAC for primary therapy, and the global salvage rate at 48 months post-IAC significantly increased, from $68 \%$ in the late 2000 s to $92.7 \%$ between 2010 and $2014^{17}$. Shields et al. reported $100 \%$ ocular salvage for ICRB class B and $\mathrm{C}$ eyes, for which IAC was used as primary treatment ${ }^{18}$. IAC has also been demonstrated to be highly efficacious for
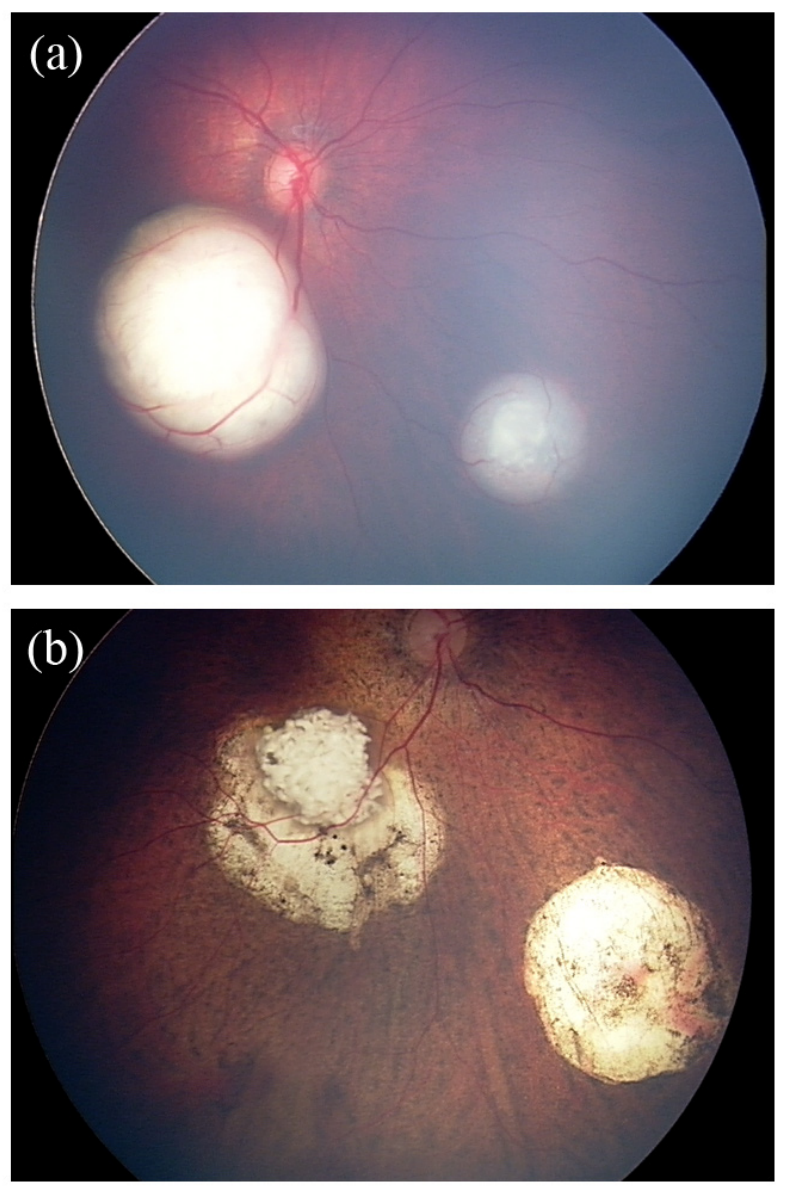

Figure 1. Retinoblastoma of a 5-month-old patient before and after intra-arterial chemotherapy (IAC). (a) Fundus photograph of the right eye before IAC, demonstrating macular and inferonasal lesions. (b) Fundus photograph of the same eye 13 months after the initial IAC treatment. The patient underwent three IAC cycles and adjuvant therapy, including five sessions of laser ablation and two sessions of cryotherapy.

advanced tumors, and 5-year ocular survival exceeded $70 \%$ for class D tumors ${ }^{18-20}$. Class E tumors show mixed results: ocular salvage ranged from $30 \%$ to $70 \%$ in the literature ${ }^{18-20}$.

Age and weight threshold for intra-arterial chemotherapy Whereas the safety and efficacy of IAC have been well demonstrated in multiple studies over the past decade, the guideline for age and weight threshold for IAC has not yet been strictly defined. It has generally been assumed that IAC should be reserved until patients with retinoblastoma reach a weight of $10 \mathrm{~kg}$ or the equivalent age because of potential procedural complications, such as groin hematomas or femoral artery dissection $^{21}$. However, several studies have recently demonstrated that patients with retinoblastoma who are younger than 3 months of age can be successfully treated with IAC $^{22,23}$. The safety of IAC can be further enhanced with ultrasound guidance for femoral artery catheterization, which has long been used in various kinds of pediatric procedures. A pilot study of six patients with 
retinoblastoma ${ }^{24}$ demonstrated no procedural complications when IAC was administered with ultrasound guidance to patients with a median weight of $9.2 \mathrm{~kg}$ at the first IAC cycle. Recent literature suggests that younger and treatment-naïve patients may achieve better oncologic efficacy when they receive a minimal number of IAC cycles ${ }^{25,26}$. Also, Gobin et al. reported that eyes that received IAC as primary treatment had an ocular event-free survival rate of $81.7 \%$ after 2 years, which was significantly higher than the rate of $58.4 \%$ for the eyes that had undergone IVC or EBR prior to $\mathrm{IAC}^{27}$. Therefore, unless there are known contraindications for IAC, such as metastatic retinoblastoma, optimal treatment outcomes may be achieved when the patients undergo IAC at the earliest age possible.

\section{Intravitreal melphalan for treating vitreous seeds}

Vitreous seeds are groups of tumor cells that break off from the primary lesion and are commonly seen in advanced retinoblastoma. Vitreous seeds are seen in ICRB class C, D, and E. Dust, spheres, and clouds are the three forms of vitreous seeds with different patterns of response to chemotherapy which have been previously characterized ${ }^{28}$. IAC has limited efficacy for vitreous seeds because of the avascular nature of the vitreous. Intravitreal injections of chemotherapy via the pars plana have now been widely adopted for persistent or recurrent vitreous seeds after primary treatment with IAC or systemic chemotherapy $^{28-30}$. In general, intravitreal melphalan or topotecan is combined with a simultaneous treatment of the retinal tumors from which the vitreous seeds originate. To prevent any potential extension of tumor seeds via the needle tract, clinicians typically take various safety measures, including cryotherapy applied to the needle site, visualization of the pars plana with ultrasound biomicroscopy, washing of the ocular surface, and subconjunctival chemotherapy ${ }^{30,31}$. The safety and efficacy of intravitreal injection of melphalan have been demonstrated in multiple studies ${ }^{28,32}$.

\section{Intravenous chemotherapy}

IVC has been used as primary and secondary therapy for retinoblastoma for over two decades. A three-agent combination (carboplatin, vincristine, and etoposide) is commonly used ${ }^{33}$, and other agents, including topotecan or cisplatin, can be additionally administered depending on the patient's response to the agents $^{34}$. Multiple studies report that over $90 \%$ of tumor control was achieved by using IVC, especially for ICRB classes A, B, and $C^{10,35}$. IVC can be effective at managing both bilateral and germline retinoblastoma. Some investigators have reported that IVC helps in preventing extraocular secondary cancers, including trilateral retinoblastoma in which extraocular cancer occurs in the pineal or suprasellar region ${ }^{36-38}$; however, this is controversial. There are some rare but recognized side effects of IVC, including neurotoxicity, immunosuppression, secondary leukemia, nephrotoxicity, and ototoxicity ${ }^{34}$.

Radioactive plaque for persistent, recurrent retinoblastoma Owing to concerns for radiation retinopathy, radioactive plaque brachytherapy is most commonly used as rescue therapy for relatively small solitary tumors in ICRB class A or $\mathrm{B}^{39,40}$. However, plaque brachytherapy is one of the preferred secondary treatment modalities before enucleation. There have been published studies that demonstrated the efficacy of iodine-125 plaque brachytherapy as salvage treatment for retinoblastoma after both IAC and IVC $^{39,40}$.

\section{Uveal melanoma}

Uveal melanoma is a malignant cancer that occurs in 4.9 people per million in the US alone ${ }^{41}$. As the name suggests, uveal melanoma can occur in any part of the uveal tract, including the iris, ciliary body, or choroid, and the involvement of the choroid is the most common. Uveal melanoma is known to spread hematogenously, and the most common sites of metastasis in descending order are liver, lung, and bone ${ }^{42}$. Mean overall 5-year survival rate has remained stable at approximately $80 \%$ over the past several decades ${ }^{2,43}$, while the 5-year survival rate drastically decreases once the tumor metastasizes. Lifetime rates of metastases in patients with uveal melanoma are controversial, but rates reported in the scientific literature range from $25 \%$ to $50 \%$ with a median survival of 6 months to a year after the development of metastatic disease ${ }^{44-46}$. Some studies have reported a longer median survival once metastatic disease is diagnosed, but other authors claim that lead-time bias explains these results ${ }^{47}$. Upon initial diagnosis, most patients currently receive plaque brachytherapy, proton beam therapy, or enucleation, except for some iris tumors that can be surgically resected.

\section{Genetic and histopathologic analyses of uveal melanoma}

Uveal melanoma is largely due to sporadic mutations in uveal melanocytes, and inherited germline mutations that contribute to the development of this tumor are extremely rare, occurring in $3 \%$ to $4 \%$ of patients ${ }^{48}$. However, a number of publications since the early 1990 s have discussed the importance of cytogenetic changes of the cancer cells which significantly affect the prognosis. Uveal melanoma is histopathologically characterized by spindle and epithelioid cells ${ }^{49}$. Standard cytology procedures, including cell block analysis with hematoxylin-eosin stain and HMB45/Ki67 immunohistochemical stain, can identify cells acquired from biopsies. Although epithelioid cells are strongly associated with more aggressive behavior, most uveal melanomas contain mixed spindle and epithelioid cells regardless of the predisposed metastatic risk $^{49}$. One study published that epithelioid and necrotic cell types have a statistically significantly higher rate of 5-year metastatic mortality rate than other cell-type findings ${ }^{50}$. In the same study, cytopathologic classification was found to be an independent prognostic factor for metastatic death ${ }^{50}$.

In the early 1990s, Prescher et al. first reported that monosomy 3 , the abnormal presence of only one copy of chromosome 3, was a commonly observed cytogenetic abnormality in uveal melanoma $^{51}$. Since then, a number of studies focusing on the genetics of uveal melanoma have been published. Several key driver genes, including GNA11, GNAQ, BAP1, SF3B1, and EIF1AX, have been identified to be involved in the development and metastasis of the cancer ${ }^{52}$. Combinations of mutations of these genes lead to variations in the development and metastasis of uveal melanoma. Of these, GNAQ and GNA11 mutations are 
involved in the early stage of oncogenesis and occur in a mutually exclusive manner in approximately $91 \%$ of the patients $^{53}$. Because these mutations occur early in oncogenesis, neither one confers valuable prognostic information. Recently, a loss-of-function mutation of $B A P 1$, a tumor suppressor gene, was discovered to be heavily associated with more malignant types of uveal melanoma. Loss of $B A P I$ induces dedifferentiation of melanoma cells and the development of stem cell-like characteristics $^{54,55}$. On the other hand, hemizygous, gain-offunction mutations of SF3B1 and EIFIAX generally indicate a better prognosis and occur in lower-risk melanomas ${ }^{56}$. Of note, melanomas with SF3B1 mutations are associated with lateonset metastases ${ }^{57}$. BAPl, SF3B1, and EIF1AX mutations mostly occur late in tumor development and also occur in a mutually exclusive fashion ${ }^{58}$.

Gene expression profile (GEP) analysis and multiplex liganddependent probe amplification (MLPA) have been adopted by ocular oncologists to elucidate each tumor's genetic characteristics $^{59,60}$. GEP testing uses a polymerase chain reaction (PCR)-based 15-gene panel and classifies uveal melanoma as either class 1 (low risk for metastasis) or class 2 (high risk for metastasis $)^{59,61}$. Class 1 is further divided into $1 \mathrm{~A}$ and $1 \mathrm{~B}$; 1A tumors remain relatively low-risk for metastasis, whereas the risk of metastasizing in $1 \mathrm{~B}$ appears to be higher than the $1 \mathrm{~A}$ group over time. The 5-year published metastatic rates for class $1 \mathrm{~A}, 1 \mathrm{~B}$, and 2 tumors are $2 \%, 21 \%$, and $72 \%$, respectively ${ }^{58}$. It has been observed that class $1 \mathrm{~B}$ uveal melanoma, though categorized under class 1 , behaves more similarly to class 2 tumors and therefore requires close monitoring for progression to metastasis. BAPl somatic mutations are observed predominantly in class 2 tumors, whereas SF3B1 or EIFIAX mutations are seen more frequently in class 1 tumors ${ }^{54}$. It is reported that BAPl mutations can be observed in approximately $80 \%$ of metastatic uveal melanoma cells ${ }^{54}$. In another study, $71 \%, 11 \%$, and $0 \%$ of patients with primary uveal melanoma who developed metastases carried BAP1, SF3B1, and EIF1AX mutations, respectively, signifying that EIFIAX and $S F 3 B 1$ mutations generally confer a good prognosis ${ }^{62}$. In the largest single-institution case series of over 1,000 patients, 3-year Kaplan-Meier estimates for metastatic uveal melanoma were provided for the following cytogenetic abnormalities: 5\% for partial monosomy of chromosome 3; $19 \%$ for complete monosomy $3 ; 23 \%$ for loss of $6 \mathrm{q} ; 29 \%$ for loss of $8 \mathrm{p} ; 21 \%$ for gain of $8 \mathrm{q} ; 1 \%$ for disomy of 3,6 , and $8 ; 29 \%$ for complete monosomy 3, $6 \mathrm{p}$ gain, and $8 \mathrm{q}$ gain; $14 \%$ for complete monosomy of 3 , disomy of 6 , and gain of $8 \mathrm{q}$ and $8 \mathrm{p} ; 27 \%$ for complete monosomy of 3 , disomy of 6 , and gain of $8 \mathrm{q}$; and $28 \%$ for complete monosomy of 3 , disomy of 6 , gain of $8 \mathrm{q}$, and loss of $8 \mathrm{p}^{63}$.

Recently, scientists have discovered that certain uveal melanomas that express a cancer-testis antigen called preferentially expressed antigen in melanoma (PRAME) are closely associated with an increased risk of metastasis in both class 1 and 2 uveal melanomas ${ }^{64,65}$. Also, class 1 tumors that are $\mathrm{PRAME}^{+}$were found to be associated with $S F 3 B 1$ mutations and inversely to EIF1AX mutations ${ }^{65}$. A combination of SF3B1 mutations and
PRAME expression appears to contribute to late metastases in class 1 tumors ${ }^{66}$, while $\mathrm{PRAME}^{+}$class 2 tumors exhibited accelerated progression to metastases ${ }^{65}$. PRAME is currently being investigated as a potential target for immunotherapy in primary and metastatic uveal melanoma ${ }^{67}$. The Collaborative Ocular Oncology Group 2 (COOG2) is a currently enrolling multicenter prospective clinical trial in which PRAME genomics will be examined along with long-term clinical outcomes.

\section{Fine needle aspiration biopsy}

As research in melanoma genomics has grown explosively, safe and adequate acquisition of tumor cells has become increasingly important for both clinical and research purposes. Fine needle aspiration biopsy (FNAB) is performed by using smallsized needles (23-, 25-, or 27-gauge) or vitrectomy probes in either a transvitreal or a trans-scleral manner, depending on the tumor location. For tumors that are anterior to the equator with direct access to the needle, the trans-scleral method is typically chosen. For posterior tumors that are more difficult to access via a trans-scleral biopsy, transvitreal biopsy can be performed by using indirect ophthalmoscopy or standard retinal instrumentation, including chandelier lighting that gives direct visualization, and valved trocars, which serve to maintain the intraocular pressure during biopsy and prevent the tracking of tumor cells along the needle tract. After the aspiration of tumor cells, cryotherapy is applied to the needle insertion site in order to prevent any iatrogenic extraocular extension of tumor cells via the needle tract. Safety of FNAB for uveal melanoma was recently reaffirmed in a prospective, in vivo study $^{68}$. Many studies have demonstrated high cellular yield rates, ranging from $68 \%$ to over $90 \%$, for cytopathologic and genomic analyses ${ }^{69-73}$.

\section{Plaque brachytherapy}

The Collaborative Ocular Melanoma Study (COMS) found no statistically significant difference in survival between patients who underwent plaque brachytherapy and patients who underwent enucleation ${ }^{74}$. Since then, most centers have adopted plaque brachytherapy as the standard treatment for uveal melanoma. Multiple types of isotopes are used for ophthalmic brachytherapy. In the US, ${ }^{125} \mathrm{I}$ is the most frequently used radioisotope after the COMS study, whereas ${ }^{106} \mathrm{Ru}$ and ${ }^{103} \mathrm{Pd}$ are more commonly used in Europe and other countries ${ }^{75}$. ${ }^{125} \mathrm{I}$ and ${ }^{103} \mathrm{Pd}$ both emit low-energy gamma rays and thus cause less damage to surrounding healthy tissues compared with isotopes that were used in the first half of the 20th century, such as ${ }^{60} \mathrm{Co}$. ${ }^{106} \mathrm{Ru}$, on the other hand, emits beta rays and has a quicker dose fall-off ${ }^{75}$. The steeper the dose gradient, the more concentrated the radiation effect on the basal side of the tumor and conversely less radiation toward the apex. ${ }^{106} \mathrm{Ru}$ has an advantage of less radiation effect to other ocular structures compared with that of ${ }^{125} \mathrm{I}$ or ${ }^{103} \mathrm{Pd}$.

Multiple studies have demonstrated that plaque therapy and enucleation result in comparable mortality rates over 20 years of follow-up ${ }^{76}$. Iodine-125 brachytherapy has become the most commonly used treatment modality for uveal melanoma in the US with excellent clinical outcomes (Figure 2). 

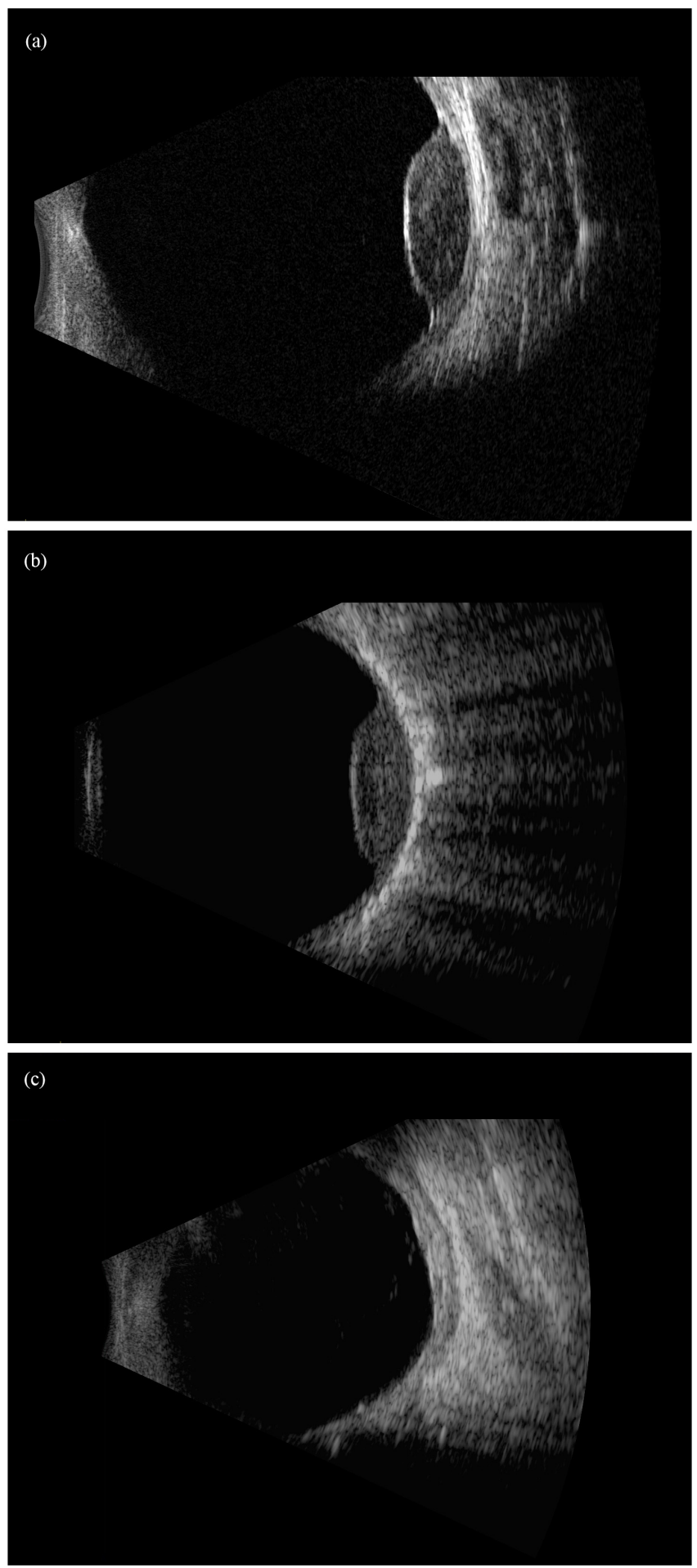

Figure 2. Uveal melanoma of a 66-year-old patient before and after plaque brachytherapy. (a) B-scan ultrasound image of the right eye before the plaque implantation. (b) B-scan ultrasound image of the same eye intraoperatively, demonstrating full coverage of the tumor with the plaque. (c) B-scan ultrasound image of the same eye 3 years after the plaque therapy, demonstrating regression of the tumor.
Local recurrence of tumor cells at the ocular site is a critical complication to be avoided after plaque therapy. Multiple studies have demonstrated that the likelihood of metastasis increases dramatically after local recurrence occurs ${ }^{77,78}$. However, the 5-year local recurrence rate has steadily decreased from $10.3 \%$ at the time of the $\mathrm{COMS}^{76}$ to $2.4 \%$ to approximately $4.7 \%$ over the past two decades. Indeed, a recent publication that reported preliminary clinical outcomes with a median follow-up of 21.6 months $^{80}$ demonstrated zero local recurrence, which may be attributed to several factors. First, newer plaque designs $^{81,82}$ are thinner than the traditional COMS plaques and are customized to conform better to each patient's eye, leading to better coverage of the tumor and less radiation scatter outside the targeted area. Second, intraoperative ultrasonographic confirmation of plaque positioning, which has been used more over the past decade, ensures precise placement of the plaque $^{83-85}$. A recent study at the Cleveland Clinic reported that plaque treatment failure decreased from $9.3 \%$ to $1.5 \%$ since intraoperative ultrasound was adopted ${ }^{86}$. Intraoperative transillumination of the tumor and preoperative 3D planning with Plaque Simulation software can further enhance the accuracy of plaque placement ${ }^{80,87}$. Treatment outcomes of plaque brachytherapy, including 5-year mortality and local recurrence rates (4\%), are comparable to those of proton beam radiotherapy in recent publications ${ }^{88,89}$. Both plaque and proton beam therapy are known to cause ocular complications, including cataracts, radiation retinopathy, and radiation optic neuropathy. The COMS demonstrated that nearly $50 \%$ of patients who receive plaque brachytherapy had significant vision loss by 3 years post-treatment because of these complications ${ }^{90}$.

\section{Clinical features with prognostic significance}

In addition to the fact that GEP class 2 melanomas have higher mortality rates than GEP class 1 tumors, several additional factors that contribute valuable prognostic information have recently been identified. Correa and Augsburger recently reported that the largest basal diameter (LBD) of the tumor can serve as an independent prognostic factor for metastasis and metastatic death ${ }^{91}$. Harbour et al. reported that class 2 tumors with an LBD over $12 \mathrm{~mm}$ had a significantly lower 5-year metastasis-free survival ${ }^{92}$. Also, increased patient age, larger tumor apical height, and ciliary body involvement of the tumor are associated with metastatic risk $^{93,94}$. Traditionally, tumors with more malignant characteristics, such as tumors with monosomy 3 or those that metastasized, were reported to regress faster after plaque therapy ${ }^{95,96}$. In recent studies, the relationship between GEP class and the tumor regression rate after brachytherapy has been controversial. Whereas several studies $^{97,98}$ found neither GEP class to be significantly associated with regression rate, another study reported that class 1 tumors regress faster ${ }^{99}$. In the largest multi-center, retrospective cohort study that was recently published, investigators also reported that class 1 tumors regress at a statistically significantly faster rate than class 2 tumors after plaque radiation $^{100}$. Future multi-center studies will help elucidate a clearer relationship between GEP class and therapeutic response to radiation. 
Molecular therapies

Some recent studies have identified several key molecular pathways associated with specific genetic mutations. For example, the BAPl gene is known to regulate histone $\mathrm{H} 2 \mathrm{~A}$ function by removing ubiquitin molecules. When the BAP1 gene is mutated, proper removal of ubiquitin from $\mathrm{H} 2 \mathrm{~A}$ is inhibited, leading to a dedifferentiated state of melanoma cells ${ }^{101}$. Also, GNAQ and GNA11 genes are closely related to transmembrane cell signaling ${ }^{52}$. Activation mutation of GNAQ or GNA11 keeps guanine nucleotide-binding proteins in an active state, which subsequently upregulates protein kinase $\mathrm{C}$ and mitogen-activated protein kinase pathways that are involved in the proliferation and differentiation of cells at the early stages of uveal melanoma oncogenesis $^{102}$. Many ongoing clinical trials (some of which are still accruing patients and some of which are now closed to new patient enrollment) are examining immunotherapy agents that target these pathways as well as several others for both high-risk and metastatic uveal melanoma (Table 3 and Table 4).

Table 3. List of ongoing clinical trials of adjuvant molecular therapy for high-risk uveal melanoma.

\begin{tabular}{|l|l|l|}
\hline ClinicalTrials.gov identifier & Study locations & Study title \\
\hline NCT02223819 & $\begin{array}{l}\text { Columbia University, New York, NY } \\
\text { Mount Sinai Comprehensive Cancer } \\
\text { Center, Miami Beach, FL } \\
\text { Memorial Sloan Kettering Cancer Center, } \\
\text { New York, NY }\end{array}$ & $\begin{array}{l}\text { Crizotinib in High-Risk Uveal Melanoma } \\
\text { Following Definitive Therapy }\end{array}$ \\
\hline NCT02068586 & $\begin{array}{l}\text { The Ohio State University, Columbus, OH } \\
\text { Thomas Jefferson University, }\end{array}$ & \\
\hline Philadelphia, PA & $\begin{array}{l}\text { Adjuvant Sunitinib or Valproic Acid in High-Risk } \\
\text { Patients With Uveal Melanoma }\end{array}$ \\
\hline
\end{tabular}

Table 4. List of ongoing clinical trials of molecular therapy for metastatic uveal melanomas.

\begin{tabular}{|c|c|c|}
\hline $\begin{array}{l}\text { ClinicalTrials.gov } \\
\text { identifier }\end{array}$ & Study locations & Study title \\
\hline NCT01979523 & $\begin{array}{l}\text { Moffitt Cancer Center, Tampa, FL } \\
\text { Emory University/Winship Cancer Institute, Atlanta, GA } \\
\text { Columbia University/Herbert Irving Cancer Center, New York, NY } \\
\text { Memorial Sloan Kettering Cancer Center, New York, NY } \\
\text { Vanderbilt University/Ingram Cancer Center, Nashville, TN } \\
\text { MD Anderson Cancer Center, Houston, TX } \\
\text { Institut Curie Paris, Paris, France } \\
\text { The University of Liverpool, Liverpool, UK }\end{array}$ & $\begin{array}{l}\text { Trametinib With or Without GSK2141795 in } \\
\text { Treating Patients With Metastatic Uveal Melanoma }\end{array}$ \\
\hline NCT01585194 & University of Texas MD Anderson Cancer Center, Houston, TX & $\begin{array}{l}\text { Phase II Study of Nivolumab in Combination With } \\
\text { Ipilimumab for Uveal Melanoma }\end{array}$ \\
\hline NCT02570308 & $\begin{array}{l}\text { Washington University, School of Medicine, St. Louis, MO } \\
\text { Columbia University Medical Center - The New York Presbyterian } \\
\text { Hospital, New York, NY } \\
\text { Thomas Jefferson University Medical Oncology Clinic, } \\
\text { Philadelphia, PA } \\
\text { The Clatterbridge Cancer Centre, Wirral, Merseyside, UK } \\
\text { Mount Vernon Cancer Centre, Northwood, Middlesex, UK }\end{array}$ & $\begin{array}{l}\text { A Study of the Intra-Patient Escalation Dosing } \\
\text { Regimen With IMCgp100 in Patients With } \\
\text { Advanced Uveal Melanoma }\end{array}$ \\
\hline
\end{tabular}




\begin{tabular}{|l|l|l|}
\hline $\begin{array}{l}\text { ClinicalTrials.gov } \\
\text { identifier }\end{array}$ & Study locations & Study title \\
\hline NCT02359851 & University of Chicago, Chicago, IL & Pembrolizumab in Treating Patients With \\
\hline NCT02273219 & $\begin{array}{l}\text { Vanderbilt-Ingram Cancer Center, Nashville, TN } \\
\text { Bascom Palmer Eye Institute of University Of Miami Medical } \\
\text { Center, Miami, FL } \\
\text { Columbia University Medical Center, New York, NY }\end{array}$ & $\begin{array}{l}\text { Trial of AEB071 in Combination With BYL719 in } \\
\text { Patients With Melanoma }\end{array}$ \\
\hline NCT01473004 & Memorial Sloan Kettering Cancer Center, New York, NY & \\
\hline NCT02678572 & $\begin{array}{l}\text { Thomas Jefferson University, Philadelphia, PA } \\
\text { Spain, Switzerland, and the UK }\end{array}$ & $\begin{array}{l}\text { SIR-Spheres 90Y Microspheres Treatment of } \\
\text { Uveal Melanoma Metastasized to Liver }\end{array}$ \\
\hline NCT01814046 & National Institutes of Health Clinical Center, Bethesda, MD & $\begin{array}{l}\text { Percutaneous Hepatic Perfusion vs Best } \\
\text { Alternative Care in Patients With Hepatic- } \\
\text { dominant Ocular Melanoma (FOCUS) }\end{array}$ \\
\hline & $\begin{array}{l}\text { Immunotherapy Using Tumor Infiltrating } \\
\text { Lymphocytes for Patients With Metastatic Ocular } \\
\text { Melanoma }\end{array}$ \\
\hline
\end{tabular}

Nanoparticle therapy

Nanoparticle therapy is an emerging cancer therapy, in which photosensitive nanoparticles preferentially bind tumor cells, followed by light activation of the nanoparticles ${ }^{103}$. This is a minimally invasive yet highly specific treatment modality that can kill tumor cells with minimal damage to the surrounding normal tissues. For uveal melanoma, a phase $1 \mathrm{~b}$ clinical trial has begun to investigate the safety of a new nanoparticle phototherapy for small to medium-sized tumors in 12 patients (http://www.aurabiosciences.com/news-archive/2017/3/30/ aura-biosciences-announces-initiation-of-phase-1b-clinicaltrial-and-receipt-of-fda-fast-track-designation-for-au-011-forthe-treatment-of-primary-ocular-melanoma). Viral nanoparticle conjugates attach to the uveal melanoma cell membrane. When activated by a $589 \mathrm{~nm}$ laser, the particles selectively break down the tumor cell membrane without affecting adjacent tissues. This treatment modality, if proven successful in clinical trials, has the potential to preserve much of the patient's vision and could be particularly groundbreaking in patients with small tumors that are close to critical ocular structures such as the optic nerve and the macula. The effect on rates of metastatic disease are still unknown.

\section{Conclusions}

Extensive advancements have been made in the understanding and treatment of retinoblastoma and uveal melanoma over the past decade. Further knowledge of intraocular cancer genetics will lead to new clinical breakthroughs that will allow us to save more eyes and lives.

\section{Competing interests}

The authors declare that they have no competing interests.

Grant information

The author(s) declared that no grants were involved in supporting this work.
1. Dimaras H, Corson TW, Cobrinik D, et al:: Retinoblastoma. Nat Rev Dis Primers. 2015; 1: 15021.

PubMed Abstract | Publisher Full Text | Free Full Text

2. Singh $A D$, Turell ME, Topham AK: Uveal melanoma: trends in incidence, treatment, and survival. Ophthalmology. 2011; 118(9): 1881-5. PubMed Abstract | Publisher Full Text

3. Chantada G, Schaiquevich P: Management of retinoblastoma in children: current status. Paediatr Drugs. 2015; 17(3): 185-98. PubMed Abstract | Publisher Full Text

4. Abramson DH, Schefler AC: Update on retinoblastoma. Retina. 2004; 24(6): 828-48. PubMed Abstract

5. Rushlow DE, Mol BM, Kennett JY, et al:: Characterisation of retinoblastomas without RB1 mutations: genomic, gene expression, and clinical studies. Lancet
Oncol. 2013; 14(4): 327-34.

PubMed Abstract | Publisher Full Text

6. Moll AC, Imhof SM, Schouten-Van Meeteren AY, et al:: Second primary tumors in hereditary retinoblastoma: a register-based study, 1945-1997: is there an age effect on radiation-related risk? Ophthalmology. 2001; 108(6): 1109-14. PubMed Abstract | Publisher Full Text

7. Linn Murphree A: Intraocular retinoblastoma: the case for a new group classification. Ophthalmol Clin North Am. 2005; 18(1): 41-53, viii. PubMed Abstract | Publisher Full Text

8. Yamane T, Kaneko A, Mohri M: The technique of ophthalmic arterial infusion therapy for patients with intraocular retinoblastoma. Int J Clin Oncol. 2004; 9(2): 69-73.

PubMed Abstract | Publisher Full Text 
9. Abramson DH, Dunkel IJ, Brodie SE, et al.: A phase I/II study of direct intraarterial (ophthalmic artery) chemotherapy with melphalan for intraocular retinoblastoma initial results. Ophthalmology. 2008; 115(8): 1398-404, 1404.e1. PubMed Abstract | Publisher Full Text

10. F Shields $\mathrm{CL}$, Jorge R, Say EA, et al:: Unilateral Retinoblastoma Managed With Intravenous Chemotherapy Versus Intra-Arterial Chemotherapy. Outcomes Based on the International Classification of Retinoblastoma. Asia Pac J Ophthalmol (Phila). 2016; 5(2): 97-103. PubMed Abstract | Publisher Full Text | F1000 Recommendation

11. F Abramson DH, Marr BP, Francis JH, et al:: Simultaneous Bilateral Ophthalmic Artery Chemosurgery for Bilateral Retinoblastoma (Tandem Therapy). PLoS One. 2016; 11(6): e0156806.

PubMed Abstract | Publisher Full Text | Free Full Text | F1000 Recommendation

12. Abruzzo TA, Geller JI, Kimbrough DA, et al.: Adjunctive techniques for optimization of ocular hemodynamics in children undergoing ophthalmic artery infusion chemotherapy. J Neurointerv Surg. 2015; 7(10): 770-6. PubMed Abstract | Publisher Full Text

13. Schefler AC, Kleinerman RA, Abramson DH: Genes and environment: effects on the development of second malignancies in retinoblastoma survivors. Expert Rev Ophthalmol. 2008; 3(1): 51-61.

PubMed Abstract | Publisher Full Text | Free Full Text

14. F Michaels ST, Abruzzo TA, Augsburger JJ, et al.: Selective Ophthalmic Artery Infusion Chemotherapy for Advanced Intraocular Retinoblastoma: CCHMC Early Experience. J Pediatr Hematol Oncol. 2016; 38(1): 65-9. PubMed Abstract | Publisher Full Text | F1000 Recommendation

15. Ramasubramanian A, Kytasty C, Meadows AT, et al:: Incidence of pineal gland cyst and pineoblastoma in children with retinoblastoma during the chemoreduction era. Am J Ophthalmol. 2013; 156(4): 825-9. PubMed Abstract | Publisher Full Text

16. F Yousef YA, Soliman SE, Astudillo PP, et al.: Intra-arterial Chemotherapy for Retinoblastoma: A Systematic Review. JAMA Ophthalmol. 2016; 134(5): 584-591. PubMed Abstract | Publisher Full Text | F1000 Recommendation

17. Abramson $\mathrm{DH}$, Fabius AW, Issa R, et al:: Advanced Unilateral Retinoblastoma: The Impact of Ophthalmic Artery Chemosurgery on Enucleation Rate and Patient Survival at MSKCC. PLoS One. 2015; 10(12): e0145436. PubMed Abstract | Publisher Full Text | Free Full Text

18. Shields CL, Manjandavida FP, Lally SE, et al.: Intra-arterial chemotherapy for retinoblastoma in 70 eyes: outcomes based on the international classification of retinoblastoma. Ophthalmology. 2014; 121(7): 1453-60. PubMed Abstract | Publisher Full Text

19. F Abramson DH, Fabius AW, Francis $\mathrm{JH}$, et al:: Ophthalmic artery chemosurgery for eyes with advanced retinoblastoma. Ophthalmic Genet. 2017; 38(1): 16-21. PubMed Abstract | Publisher Full Text | Free Full Text | F1000 Recommendation

20. $\mathrm{F}$ Chen $\mathrm{M}$, Jiang $\mathrm{H}$, Zhang J, et al.: Outcome of intra-arterial chemotherapy for retinoblastoma and its influencing factors: a retrospective study. Acta Ophthalmol. 2017; 95(6): 613-8.

PubMed Abstract | Publisher Full Text | F1000 Recommendation

21. Gobin YP, Dunkel IJ, Marr BP, et al.: Combined, sequential intravenous and intra-arterial chemotherapy (bridge chemotherapy) for young infants with retinoblastoma. PLoS One. 2012; 7(9): e44322. PubMed Abstract | Publisher Full Text | Free Full Text

22. F Chen M, Zhao J, Xia J, et al:: Intra-Arterial Chemotherapy as Primary Therapy for Retinoblastoma in Infants Less than 3 Months of Age: A Series of 10 Case-Studies. PLoS One. 2016; 11(8): e0160873.

PubMed Abstract | Publisher Full Text | Free Full Text | F1000 Recommendation

23. F Magan T, Khoo CT, Jabbour PM, et al:: Intraarterial Chemotherapy for Retinoblastoma in A 2-Month-Old Infant. Retin Cases Brief Rep. 2017; 11(1): 24-26.

PubMed Abstract | Publisher Full Text | F1000 Recommendation

24. Kim RS, Dannenbaum MJ, Lin MW, et al:: Use of Femoral Artery Ultrasound During Intraarterial Chemotherapy for Children Under $10 \mathrm{~kg}$ With Retinoblastoma. Retina. 2017.

PubMed Abstract | Publisher Full Text

25. F Shields CL, Kaliki S, Shah SU, et al:: Minimal exposure (one or two cycles) of intra-arterial chemotherapy in the management of retinoblastoma. Ophthalmology. 2012; 119(1): 188-92. PubMed Abstract | Publisher Full Text | F1000 Recommendation

26. F Dillon AB, Douglass A, Jabbour $P$, et al:: Minimal exposure intra-arterial chemotherapy for children with retinoblastoma and 13q syndrome. Oman $J$ Ophthalmol. 2016; 9(3): 164-166.

PubMed Abstract | Publisher Full Text | Free Full Text | F1000 Recommendation

27. F Gobin YP, Dunkel IJ, Marr BP, et al:: Intra-arterial chemotherapy for the management of retinoblastoma: four-year experience. Arch Ophthalmol. 2011; 129(6): 732-7.

PubMed Abstract | Publisher Full Text | F1000 Recommendation

28. Munier FL: Classification and management of seeds in retinoblastoma. Ellsworth Lecture Ghent August 24th 2013. Ophthalmic Genet. 2014; 35(4): 193-207. PubMed Abstract | Publisher Full Text | Free Full Text
29. Ghassemi F, Shields CL: Intravitreal melphalan for refractory or recurrent vitreous seeding from retinoblastoma. Arch Ophthalmol. 2012; 130(10): 1268-71. PubMed Abstract | Publisher Full Text

30. Munier FL, Gaillard MC, Balmer A, et al.: Intravitreal chemotherapy for vitreous seeding in retinoblastoma: Recent advances and perspectives. Saudi Ophthalmol. 2013; 27(3): 147-50.

PubMed Abstract | Publisher Full Text | Free Full Text

31. Francis $\mathrm{JH}$, Abramson $\mathrm{DH}, \mathrm{Ji}$ X, et al:: Risk of Extraocular Extension in Eyes With Retinoblastoma Receiving Intravitreous Chemotherapy. JAMA Ophthalmol. 2017; 135(12): 1426-9.

PubMed Abstract | Publisher Full Text

32. $\mathrm{F}$ Munier FL, Soliman S, Moulin AP, et al:: Profiling safety of intravitreal injections for retinoblastoma using an anti-reflux procedure and sterilisation of the needle track. Br J Ophthalmol. 2012; 96(8): 1084-7. PubMed Abstract | Publisher Full Text | F1000 Recommendation

33. Kingston JE, Hungerford JL, Madreperla SA, et al:: Results of combined chemotherapy and radiotherapy for advanced intraocular retinoblastoma. Arch Ophthalmol. 1996; 114(11): 1339-43.

PubMed Abstract | Publisher Full Text

34. F Mendoza PR, Grossniklaus HE: Therapeutic Options for Retinoblastoma. Cancer Control. 2016; 23(2): 99-109.

PubMed Abstract | Publisher Full Text | F1000 Recommendation

35. Shields CL, Mashayekhi A, Au AK, et al:: The International Classification of Retinoblastoma predicts chemoreduction success. Ophthalmology. 2006; 113(12): 2276-80.

PubMed Abstract | Publisher Full Text

36. Shields CL, Shields JA, Meadows AT: Chemoreduction for retinoblastoma may prevent trilateral retinoblastoma. J Clin Oncol. 2000; 18(1): 236-7.

PubMed Abstract | Publisher Full Tex

37. Dunkel IJ, Jubran RF, Gururangan S, et al:: Trilateral retinoblastoma: potentially curable with intensive chemotherapy. Pediatr Blood Cancer. 2010; 54(3): 384-7. PubMed Abstract | Publisher Full Text

38. F Ortiz MV, Dunkel IJ: Retinoblastoma. J Child Neurol. 2016; 31(2): 227-36. PubMed Abstract | Publisher Full Text | F1000 Recommendation

39. Shields $\mathrm{CL}$, Mashayekhi $\mathrm{A}$, Sun $\mathrm{H}$, et al.: lodine 125 plaque radiotherapy as salvage treatment for retinoblastoma recurrence after chemoreduction in 84 tumors. Ophthalmology. 2006; 113(11): 2087-92.

PubMed Abstract | Publisher Full Text

40. Francis $\mathrm{JH}$, Barker $\mathrm{CA}$, Wolden $\mathrm{SL}$, et al: Salvage/adjuvant brachytherapy after ophthalmic artery chemosurgery for intraocular retinoblastoma. Int $J$ Radiat Oncol Biol Phys. 2013; 87(3): 517-23.

PubMed Abstract | Publisher Full Text | Free Full Text

41. McLaughlin CC, Wu XC, Jemal A, et al:: Incidence of noncutaneous melanomas in the U.S. Cancer. 2005; 103(5): 1000-7.

PubMed Abstract | Publisher Full Text

42. Collaborative Ocular Melanoma Study Group: Assessment of metastatic disease status at death in $\mathbf{4 3 5}$ patients with large choroidal melanoma in the Collaborative Ocular Melanoma Study (COMS): COMS report no. 15. Arch Ophthalmol. 2001; 119(5): 670-6.

PubMed Abstract | Publisher Full Text

43. Singh AD, Topham A: Survival rates with uveal melanoma in the United States: 1973-1997. Ophthalmology. 2003; 110(5): 962-5.

PubMed Abstract | Publisher Full Text

44. Diener-West M, Reynolds SM, Agugliaro DJ, et al:: Development of metastatic disease after enrollment in the COMS trials for treatment of choroidal melanoma: Collaborative Ocular Melanoma Study Group Report No. 26. Arch Ophthalmol. 2005; 123(12): 1639-43. PubMed Abstract | Publisher Full Text

45. Kujala E, Mäkitie T, Kivelä T: Very long-term prognosis of patients with malignant uveal melanoma. Invest Ophthalmol Vis Sci. 2003; 44(11): 4651-9. PubMed Abstract | Publisher Full Text

46. Diener-West M, Earle JD, Fine SL, et al:: The CoMS randomized trial of iodine 125 brachytherapy for choroidal melanoma, III: initial mortality findings. COMS Report No. 18. Arch Ophthalmol. 2001; 119(7): 969-82.

PubMed Abstract | Publisher Full Text

47. Kim IK, Lane AM, Gragoudas ES: Survival in patients with presymptomatic diagnosis of metastatic uveal melanoma. Arch Ophthalmol. 2010; 128(7): 871-5. PubMed Abstract | Publisher Full Text

48. F Njauw CN, Kim I, Piris A, et al:: Germline BAP1 inactivation is preferentially associated with metastatic ocular melanoma and cutaneous-ocular melanoma families. PLoS One. 2012; 7(4): e35295.

PubMed Abstract | Publisher Full Text | Free Full Text | F1000 Recommendation

49. Collaborative Ocular Melanoma Study Group: Histopathologic characteristics of uveal melanomas in eyes enucleated from the Collaborative Ocular Melanoma Study. COMS report no. 6. Am J Ophthalmol. 1998; 125(6): 745-66. PubMed Abstract | Publisher Full Text

50. Augsburger JJ, Corrêa ZM, Trichopoulos N: Prognostic implications of cytopathologic classification of melanocytic uveal tumors evaluated by fineneedle aspiration biopsy. Arq Bras Oftalmol. 2013; 76(2): 72-9.

PubMed Abstract | Publisher Full Text 
51. Prescher G, Bornfeld N, Becher R: Nonrandom chromosomal abnormalities in primary uveal melanoma. J Natl Cancer Inst. 1990; 82(22): 1765-9. PubMed Abstract | Publisher Full Text

52. $\mathrm{F}$ Helgadottir $\mathrm{H}$, Höiom $\mathrm{V}$ : The genetics of uveal melanoma: current insights. Appl Clin Genet. 2016; 9: 147-55.

PubMed Abstract | Publisher Full Text | Free Full Text | F1000 Recommendation

53. F Daniels AB, Lee JE, MacConaill LE, et al:: High throughput mass spectrometry-based mutation profiling of primary uveal melanoma. Invest Ophthalmol Vis Sci. 2012; 53(11): 6991-6.

PubMed Abstract | Publisher Full Text | Free Full Text | F1000 Recommendation

54. F Harbour JW, Onken MD, Roberson ED, et al.: Frequent mutation of BAP1 in metastasizing uveal melanomas. Science. 2010; 330(6009): 1410-3. PubMed Abstract | Publisher Full Text | Free Full Text | F1000 Recommendation

55. Chang SH, Worley LA, Onken MD, et al:: Prognostic biomarkers in uveal melanoma: evidence for a stem cell-like phenotype associated with metastasis. Melanoma Res. 2008; 18(3): 191-200. PubMed Abstract | Publisher Full Text

56. Martin $\mathrm{M}, \mathrm{Maßhöfer} \mathrm{L}$, Temming $\mathrm{P}$, et al:: Exome sequencing identifies recurrent somatic mutations in EIF1AX and SF3B1 in uveal melanoma with disomy 3. Nat Genet. 2013; 45(8): 933-6.

PubMed Abstract | Publisher Full Text | Free Full Text

57. F Yavuzyigitoglu S, Koopmans AE, Verdijk RM, et al.: Uveal Melanomas with SF3B1 Mutations: A Distinct Subclass Associated with Late-Onset Metastases. Ophthalmology. 2016; 123(5): 1118-28.

PubMed Abstract | Publisher Full Text | F1000 Recommendation

58. Field MG, Harbour JW: Recent developments in prognostic and predictive testing in uveal melanoma. Curr Opin Ophthalmol. 2014; 25(3): 234-9. PubMed Abstract | Publisher Full Text | Free Full Text

59. Onken MD, Worley LA, Ehlers JP, et al.: Gene expression profiling in uvea melanoma reveals two molecular classes and predicts metastatic death. Cancer Res. 2004; 64(20): 7205-9.

PubMled Abstract | Publisher Full Text | Free Full Text

60. Damato B, Dopierala J, Klaasen A, et al.: Multiplex ligation-dependent probe amplification of uveal melanoma: correlation with metastatic death. Invest Ophthalmol Vis Sci. 2009; 50(7): 3048-55.

PubMed Abstract | Publisher Full Text

61. Harbour JW, Chen R: The DecisionDx-UM Gene Expression Profile Test Provides Risk Stratification and Individualized Patient Care in Uveal Melanoma. PLoS Curr. 2013; 5: pii: ecurrents.eogt. af8ba80fc776c8f1ce8f5dc485d4a618. PubMed Abstract | Publisher Full Text | Free Full Text

62. F Decatur CL, Ong E, Garg N, et al.: Driver Mutations in Uveal Melanoma: Associations With Gene Expression Profile and Patient Outcomes. JAMA Ophthalmol. 2016; 134(7): 728-33.

PubMed Abstract | Publisher Full Text | Free Full Text | F1000 Recommendation

63. F Shields CL, Say EAT, Hasanreisoglu M, et al:: Personalized Prognosis of Uveal Melanoma Based on Cytogenetic Profile in 1059 Patients over an 8-Year Period: The 2017 Harry S. Gradle Lecture. Ophthalmology. 2017; 124(10): 1523-31. PubMed Abstract | Publisher Full Text | F1000 Recommendation

64. F Field MG, Decatur CL, Kurtenbach S, et al:: PRAME as an Independent Biomarker for Metastasis in Uveal Melanoma. Clin Cancer Res. 2016; 22(5): 1234-42.

PubMed Abstract | Publisher Full Text | Free Full Text | F1000 Recommendation

65. F Field MG, Durante MA, Decatur CL, et al.: Epigenetic reprogramming and aberrant expression of PRAME are associated with increased metastatic risk in Class 1 and Class 2 uveal melanomas. Oncotarget. 2016; 7(37): 59209-19. PubMed Abstract | Publisher Full Text | Free Full Text | F1000 Recommendation

66. $F$ Reichstein D: New concepts in the molecular understanding of uveal melanoma. Curr Opin Ophthalmol. 2017; 28(3): 219-27. PubMed Abstract | Publisher Full Text | F1000 Recommendation

67. F Gezgin G, Luk SJ, Cao J, et al.: PRAME as a Potential Target for Immunotherapy in Metastatic Uveal Melanoma. JAMA Ophthalmol. 2017; 135(6): 541-9.

PubMed Abstract | Publisher Full Text | Free Full Text | F1000 Recommendation

68. Kim RS, Chevez-Barrios P, Bretana ME, et al.: Histopathologic Analysis of Transvitreal Fine Needle Aspiration Biopsy Needle Tracts for Uveal Melanoma. Am J Ophthalmol. 2017; 174: 9-16. PubMed Abstract | Publisher Full Text

69. Shields CL, Ganguly A, Materin MA, et al:: Chromosome $\mathbf{3}$ analysis of uveal melanoma using fine-needle aspiration biopsy at the time of plaque radiotherapy in 140 consecutive cases. Trans Am Ophthalmol Soc. 2007; 105 43-52; discussion 52-3. PubMed Abstract | Free Full Text

70. F Chang MY, McCannel TA: Comparison of uveal melanoma cytopathologic sample retrieval in trans-scleral versus vitrectomy-assisted transvitreal fine needle aspiration biopsy. Br J Ophthalmol. 2014; 98(12): 1654-8. PubMed Abstract | Publisher Full Text | F1000 Recommendation

71. F Sellam A, Desjardins L, Barnhill R, et al.: Fine Needle Aspiration Biopsy in Uveal Melanoma: Technique, Complications, and Outcomes. Am J Ophthalmol.
2016; 162: 28-34.e1.

PubMed Abstract | Publisher Full Text | F1000 Recommendation

72. $\mathrm{F}$ Singh $\mathrm{AD}$, Medina $\mathrm{CA}$, Singh $\mathrm{N}$, et al:: Fine-needle aspiration biopsy of uvea melanoma: outcomes and complications. Br J Ophthalmol. 2016; 100(4): 456-62. PubMed Abstract | Publisher Full Text | F1000 Recommendation

73. Correa ZM, Augsburger JJ: Sufficiency of FNAB aspirates of posterior uveal melanoma for cytologic versus GEP classification in 159 patients, and relative prognostic significance of these classifications. Graefes Arch Clin Exp Ophthalmol. 2014; 252(1): 131-5.

PubMed Abstract | Publisher Full Text | Free Full Text

74. Jampol LM, Moy CS, Murray TG, et al:: The COMS randomized trial of iodine 125 brachytherapy for choroidal melanoma: IV. Local treatment failure and enucleation in the first 5 years after brachytherapy. COMS report no. 19. Ophthalmology. 2002; 109(12): 2197-206. PubMed Abstract | Publisher Full Text

75. Nag S, Quivey JM, Earle JD, et al.: The American Brachytherapy Society recommendations for brachytherapy of uveal melanomas. Int $J$ Radiat Oncol Biol Phys. 2003; 56(2): 544-55.

PubMed Abstract | Publisher Full Text

76. Collaborative Ocular Melanoma Study Group: The COMS randomized trial of iodine 125 brachytherapy for choroidal melanoma: V. Twelve-year mortality rates and prognostic factors: COMS report No. 28. Arch Ophthalmol. 2006; 124(12): 1684-93.

PubMed Abstract | Publisher Full Text

77. F Ophthalmic Oncology Task Force: Local Recurrence Significantly Increases the Risk of Metastatic Uveal Melanoma. Ophthalmology. 2016; 123(1): 86-91. PubMed Abstract | Publisher Full Text | F1000 Recommendation

78. Harbour JW, Char DH, Kroll S, et al:: Metastatic risk for distinct patterns of postirradiation local recurrence of posterior uveal melanoma. Ophthalmology. 1997; 104(11): 1785-92; discussion 1792-3.

PubMed Abstract | Publisher Full Text

79. Berry JL, Dandapani SV, Stevanovic M, et al:: Outcomes of choroidal melanomas treated with eye physics: a 20-year review. JAMA Ophthalmol. 2013; 131(11): 1435-42.

PubMed Abstract | Publisher Full Text

80. Tann AW, Teh BS, Scarboro SB, et al.: Early outcomes of uveal melanoma treated with intraoperative ultrasound guided brachytherapy using custom built plaques. Pract Radiat Oncol. 2017; 7(4): e275-e282.

PubMed Abstract | Publisher Full Text

81. Astrahan MA, Luxton $\mathrm{G}, \mathrm{Pu} \mathrm{Q}$, et al:: Conformal episcleral plaque therapy. Int J Radiat Oncol Biol Phys. 1997; 39(2): 505-19. PubMed Abstract | Publisher Full Text

82. Astrahan MA, Luxton G, Jozsef G, et al.: Optimization of ${ }^{125}$ ophthalmic plaque brachytherapy. Med Phys. 1990; 17(6): 1053-7. PubMed Abstract | Publisher Full Text

83. Harbour JW, Murray TG, Byrne SF, et al:: Intraoperative echographic localization of iodine 125 episcleral radioactive plaques for posterior uveal melanoma. Retina. 1996; 16(2): 129-34.

PubMed Abstract

84. Tabandeh H, Chaudhry NA, Murray TG, et al:: Intraoperative echographic localization of iodine-125 episcleral plaque for brachytherapy of choroidal melanoma. Am J Ophthalmol. 2000; 129(2): 199-204.

PubMed Abstract | Publisher Full Text

85. Finger PT: Intraoperative echographic localization of iodine-125 episcleral plaque for brachytherapy of choroidal melanoma. Am J Ophthalmol. 2000; 130(4): 539-40. PubMed Abstract | Publisher Full Text

86. F Aziz HA, Al Zahrani YA, Bena J, et al:: Episcleral brachytherapy of uveal melanoma: role of intraoperative echographic confirmation. Br J Ophthalmol. 2017; 101(6): 747-51. PubMed Abstract | Publisher Full Text | F1000 Recommendation

87. Astrahan MA, Luxton G, Jozsef G, et al:: An interactive treatment planning system for ophthalmic plaque radiotherapy. Int J Radiat Oncol Biol Phys. 1990; 18(3): 679-87.

PubMed Abstract | Publisher Full Text

88. Wang Z, Nabhan M, Schild SE, et al.: Charged particle radiation therapy for uveal melanoma: a systematic review and meta-analysis. Int $J$ Radiat Oncol Biol Phys. 2013; 86(1): 18-26.

PubMed Abstract | Publisher Full Text

89. F Mishra KK, Daftari IK: Proton therapy for the management of uveal melanoma and other ocular tumors. Chin Clin Oncol. 2016; 5(4): 50. PubMed Abstract | Publisher Full Text | F1000 Recommendation

90. Melia BM, Abramson DH, Albert DM, et al.: Collaborative ocular melanoma study (COMS) randomized trial of $\mathrm{l}-125$ brachytherapy for medium choroidal melanoma. I. Visual acuity after 3 years COMS report no. 16 . Ophthalmology. 2001; 108(2): 348-66. PubMed Abstract | Publisher Full Text

91. F Corrêa ZM, Augsburger JJ: Independent Prognostic Significance of Gene Expression Profile Class and Largest Basal Diameter of Posterior Uveal Melanomas. Am J Ophthalmol. 2016; 162: 20-27.e1. PubMed Abstract | Publisher Full Text | F1000 Recommendation 
92. F Walter SD, Chao DL, Feuer W, et al:: Prognostic Implications of Tumor Diameter in Association With Gene Expression Profile for Uveal Melanoma. JAMA Ophthalmol. 2016; 134(7): 734-40.

PubMed Abstract | Publisher Full Text | Free Full Text | F1000 Recommendation

93. Schefler A, Berry D, Seider M, et al: Ocular Oncology Study Consortium Report 3: Baseline clinical features and relationship to GEP Class. Association for Research in Vision and Ophthalmology. Baltimore, MD. 2017.

94. Chew AL, Spilsbury K, Isaacs TW: Survival from uveal melanoma in Western Australia 1981-2005. Clin Exp Ophthalmol. 2015; 43(5): 422-8. PubMed Abstract | Publisher Full Text

95. Kaiserman I, Anteby I, Chowers I, et al:: Post-brachytherapy initial tumour regression rate correlates with metastatic spread in posterior uveal melanoma. Br J Ophthalmol. 2004; 88(7): 892-5.

PubMed Abstract | Publisher Full Text | Free Full Text

96. Shields CL, Bianciotto C, Rudich D, et al:: Regression of uveal melanoma after plaque radiotherapy and thermotherapy based on chromosome 3 status. Retina. 2008; 28(9): 1289-95. PubMed Abstract | Publisher Full Text

97. F Gupta K, McCannel CA, Kamrava M, et al:: Tumor-height regression rate after brachytherapy between choroidal melanoma gene expression profile classes: effect of controlling for tumor height. Graefes Arch Clin Exp Ophthalmol. 2016; 254(7): 1371-8.

Ophthalmol. 2016; 254(7): 1371-8.
PubMed Abstract | Publisher Full Text | F1000 Recommendation
98. Corrêa ZM, Augsburger JJ: Relationship between rate of posterior uvea melanoma flattening following plaque radiotherapy and gene expression profile class of tumor cells. Invest Ophthalmol Vis Sci. 2014; 55(1): 556-9. PubMed Abstract | Publisher Full Text

99. Rao RC, Khan M, Badiyan SN, et al.: Gene expression profiling and regression rate of irradiated uveal melanomas. Ophthalmic Surg Lasers Imaging Retina. 2015; 46(3): 333-7.

PubMed Abstract | Publisher Full Text | Free Full Text

100. Mruthyunjaya P, Seider MI, Stinnett S, et al:: Association between Tumor Regression Rate and Gene Expression Profile after lodine 125 Plaque Radiotherapy for Uveal Melanoma. Ophthalmology. 2017; 124(10): 1532-9. PubMed Abstract | Publisher Full Text

101. Landreville S, Agapova OA, Matatall KA, et al:: Histone deacetylase inhibitors induce growth arrest and differentiation in uveal melanoma. Clin Cancer Res. 2012; 18(2): 408-16.

PubMed Abstract | Publisher Full Text | Free Full Text

102. Chen $X, W u Q$, Tan $L$, et al:: Combined PKC and MEK inhibition in uveal melanoma with GNAQ and GNA11 mutations. Oncogene. 2014; 33(39): 4724-34.

PubMed Abstract | Publisher Full Text | Free Full Text

103. Nowis D, Makowski M, Stoklosa T, et al.: Direct tumor damage mechanisms of photodynamic therapy. Acta Biochim Pol. 2005; 52(2): 339-52.

PubMed Abstract 


\section{Open Peer Review}

\section{Current Peer Review Status:}

\section{Editorial Note on the Review Process}

Faculty Reviews are review articles written by the prestigious Members of Faculty Opinions. The articles are commissioned and peer reviewed before publication to ensure that the final, published version is comprehensive and accessible. The reviewers who approved the final version are listed with their names and affiliations.

\section{The reviewers who approved this article are:}

\section{Version 1}

\section{Richard Carvajal}

Division of Hematology/Oncology, Columbia University Medical Center, New York, NY, USA

Competing Interests: Aura Biosciences - Clinical Advisor ICONIC Therapeutics - Consulting Castle Biosciences - Consulting

\section{Zelia Correa (iD}

Department of Ophthalmology, University of Cincinnati, Cincinnati, OH, USA

Competing Interests: No competing interests were disclosed.

The benefits of publishing with F1000Research:

- Your article is published within days, with no editorial bias

- You can publish traditional articles, null/negative results, case reports, data notes and more

- The peer review process is transparent and collaborative

- Your article is indexed in PubMed after passing peer review

- Dedicated customer support at every stage

For pre-submission enquiries, contact research@f1000.com 